\title{
Apoptotic effect of noscapine in breast cancer cell lines
}

\author{
EDWIN O. QUISBERT-VALENZUELA ${ }^{1}$ and GLORIA M. CALAF ${ }^{1,2}$ \\ ${ }^{1}$ Institute for Advanced Research, University of Tarapacá, Arica 8097877, Chile; ${ }^{2}$ Center for Radiological Research, \\ Columbia University Medical Center, New York, NY 10032, USA \\ Received January 14, 2016; Accepted February 20, 2016
}

DOI: $10.3892 /$ ijo.2016.3476

\begin{abstract}
Cancer is a public health problem in the world and breast cancer is the most frequently cancer in women. Approximately $15 \%$ of the breast cancers are triple-negative. Apoptosis regulates normal growth, homeostasis, development, embryogenesis and appropriate strategy to treat cancer. Bax is a protein pro-apoptotic enhancer of apoptosis in contrast to $\mathrm{Bcl}-2$ with antiapoptotic properties. Initiator caspase-9 and caspase- 8 are features of intrinsic and extrinsic apoptosis pathway, respectively. NF- $\mathrm{BB}$ is a transcription factor known to be involved in the initiation and progression of breast cancer. Noscapine, an alkaloid derived from opium is used as antitussive and showed antitumor properties that induced apoptosis in cancer cell lines. The aim of the present study was to determine the apoptotic effect of noscapine in breast cancer cell lines compared to breast normal cell line. Three cell lines were used: i) a control breast cell line MCF-10F; ii) a luminallike adenocarcinoma triple-positive breast cell line MCF-7; iii) breast cancer triple-negative cell line MDA-MB-231. Our results showed that noscapine had lower toxicity in normal cells and was an effective anticancer agent that induced apoptosis in breast cancer cells because it increases Bax gene and protein expression in three cell lines, while decreases $B c l-x L$ gene expression, and $\mathrm{Bcl}-2$ protein expression decreased in breast cancer cell lines. Therefore, $\mathrm{Bax} / \mathrm{Bcl}-2$ ratio increased in the three cell lines. This drug increased caspase- 9 gene expression in breast cancer cell lines and caspase- 8 gene expression increased in MCF-10F and MDA-MB-231. Furthermore, it increased cleavage of caspase- 8 , suggesting that noscapineinduced apoptosis is probably due to the involvement of extrinsic and intrinsic apoptosis pathways. Antiapoptotic gene and protein expression diminished and proapoptotic gene and protein expression increased noscapine-induced expression, probably due to decrease in $\mathrm{NF}-\kappa \mathrm{B}$ gene and protein expression and also by increase of $I \kappa B \alpha$ gene expression induced by this drug.
\end{abstract}

Correspondence to: Dr Gloria M. Calaf, Institute for Advanced Research, University of Tarapacá, Calle Antofagasta 1520, Arica 8097877, Chile

E-mail: gmc24@cumc.columbia.edu

Key words: breast cancer, cell lines, NF-кB, apoptosis, noscapine

\section{Introduction}

Cancer is a leading cause of death in both more and less economically developed countries; the burden is expected to grow worldwide due to the growth and aging of the population and improvements in early detection and treatment (1). Cancer is a major public health problem in many parts of the world. It is currently the second leading cause of death in the United States $(1,2)$. Breast cancer, is the most frequently occurring cancer in women and some cases show slow growth with excellent prognosis, while aggressive tumors have poor prognosis (1-3). Breast tumors have also been identified into different subtypes based on the expression of estrogen receptors (ER), progesterone receptors (PR) and Her2 oncogene. The breast tumors that do not express ER, PR or Her2 are called triple-negative breast cancers and $\sim 15 \%$ of the breast cancers fall into this category $(3,4)$.

Apoptosis is a process of programmed cell death that occurs in response to environmental stimuli and normal growth and homeostasis, during development, embryogenesis, modification of normal tissues, and appropriate strategy for prevention and treatment of cancer $(5,6)$. Bcl-2 protein family plays an important role in the survival or death of a cell and in recent years these proteins have been the target of many antitumor drugs (7). Bax is a protein pro-apoptotic that operates as an enhancer of apoptosis in contrast to Bcl-2 with antiapoptotic properties. The interactions between both in the cytosol and on mitochondria determine the fate of the cell for death or survival (8). Gene and protein expression of Bax in breast cancer cells increase sensitivity to apoptotic stimuli and decreases tumor enlargement while, $\mathrm{Bcl}-\mathrm{xL}$ is another anti-apoptotic protein that inhibits apoptosis and stimulates the progress of breast cancer $(6,7,9)$. In cancer cells, it has been demonstrated that the $\mathrm{Bax} / \mathrm{Bcl}-2$ ratio is diminished favoring the survival of cells, but treatment with anticancer drugs increased Bax/Bcl-2 ratio producing cell apoptosis by the intrinsic pathway $(6,10-12)$.

Caspase activity has been related to the different pathways of apoptosis, caspase- 8 and caspase- 10 features of the extrinsic pathway, whereas caspase- 9 of the intrinsic pathway. Caspase- 8 and caspase-9 (among others) are initiators of apoptosis and their activation triggers the caspase-3 effector, therefore, their increase stimulate apoptosis $(5,13,14)$. On the contrary, nuclear factor kappa-light-chain-enhancer of activated B cells $(\mathrm{NF}-\kappa \mathrm{B})$ is a pro-inflammatory and pro-survival transcription factor and it is known to be highly involved in the initiation and 
progression of breast cancer. Dysregulation of $\mathrm{NF}-\kappa \mathrm{B}$ activity alters the expression of cell death-regulating genes, leading to the upregulation of antiapoptotic and pro-survival genes, such as members of the Bcl-2 family. Protein inhibitors of $\kappa \mathrm{B}(\mathrm{I} \kappa \mathrm{B})$ suppress activation of NF- $\kappa B$ (15-17). The inhibitors include $\mathrm{I} \kappa \mathrm{B} \alpha, \mathrm{I} \kappa \mathrm{B} \beta, \mathrm{I} \kappa \mathrm{B} \varepsilon$ and $\mathrm{I} \kappa \mathrm{B} \zeta$.

Noscapine is a phthalideisoquinoline alkaloid derived from opium that has been used as an antitussive in humans and in animal experiments. Some studies have shown anxiolytic effects in mice. This is also a drug with low toxicity and good tolerance, animal studies showed a wide margin of safety in both acute and chronic treatment. Previous studies have shown that noscapine is also an agent with antitumor properties that produces alterations in cell cycle progression and consequently induces apoptosis in cell lines of different cancers (18-20). These features make it an attractive drug for the study in the management of breast cancer. The aim of the present study was to determine the effect of noscapine on gene and protein expression involved in apoptosis in breast cancer cell lines compared to a breast normal cell line.

\section{Materials and methods}

Cell lines and drug. In these studies three cell lines were used: i) a control epithelial cell line breast MCF-10F spontaneously immortalized; ii) a luminal-like adenocarcinoma triple positive cell line MCF-7; and iii) breast cancer triple-negative cell line MDA-MB-231. MCF-10F was grown in Dulbecco's modified Eagle's medium (DMEM)/F-12 (1:1) supplemented with antibiotics $100 \mathrm{U} / \mathrm{ml}$ penicillin, $100 \mu \mathrm{g} / \mathrm{ml}$ streptomycin, $2.5 \mu \mathrm{g} / \mathrm{ml}$ amphotericin B (all from Life Technologies, Grand Island, NY, USA), 5\% horse serum (Biofluids, Rockville, MD, USA), $10 \mu \mathrm{g} / \mathrm{ml}$ insulin (Sigma-Aldrich, St. Louis, MO, USA), $0.5 \mathrm{mg} / \mathrm{ml}$ hydrocortisone (Sigma) and $0.02 \mu \mathrm{g} / \mathrm{ml}$ epidermal growth factor (Collaborative Research, Inc., Bedford, MA, USA) at the temperature of $37^{\circ} \mathrm{C}$ and $5 \%$ concentration of $\mathrm{CO}_{2}$. MCF-7 cell line was cultivated in the Dulbecco's modified medium (Sigma-Aldrich, GmbH, Munich, Germany) supplemented with antibiotics $100 \mathrm{U} / \mathrm{ml}$ penicillin, $100 \mu \mathrm{g} / \mathrm{ml}$ streptomycin, $2.5 \mu \mathrm{g} / \mathrm{ml}$ amphotericin B and $10 \%$ fetal calf serum at the temperature of $37^{\circ} \mathrm{C}$ and $5 \%$ concentration of $\mathrm{CO}_{2}$. MDA-MB-231 cell line was purchased from the American Type Culture Collection (ATCC; Manassas, VA, USA) and was maintained DMEM supplemented with antibiotics $100 \mathrm{U} / \mathrm{ml}$ penicillin, $100 \mu \mathrm{g} / \mathrm{ml}$ streptomycin, $2.5 \mu \mathrm{g} / \mathrm{ml}$ amphotericin $\mathrm{B}$ and $10 \%$ fetal bovine serum (FBS) at the temperature of $37^{\circ} \mathrm{C}$ and $5 \%$ concentration of $\mathrm{CO}_{2}$. Noscapine (97\% purity) was obtained from Sigma-Aldrich. The noscapine stock solution was prepared at $100 \mathrm{mM}$ in dimethyl sulfoxide (DMSO) (Sigma) and kept at $-20^{\circ} \mathrm{C}$ until use.

MTT assay. The metabolic activity of living cells, as indicator of cell viability, was determined by 3-(4,5-dimethylthiazol2-yl)-2,5-diphenyltetrazolium bromide (MTT) assay. The MCF-10F, MCF-7 and MDA-MB-231 cell lines were seeded in 24-well microplates $\left(25 \times 10^{3}\right.$ cells/well) and incubated in culture medium for 24 and $48 \mathrm{~h}$ at temperature $37^{\circ} \mathrm{C}$ and $5 \%$ concentration of $\mathrm{CO}_{2}$. After incubation the cells were treated with $20,40,60,80$ and $100 \mu \mathrm{M}$ of noscapine. Subsequently to the treatment of cells, reduction of MTT was determined following the manufacturer's instructions. The treatment groups were compared with the control group and the results were expressed as percentage of viable cells.

Western blotting. The cells were lysed with $1 \mathrm{ml}$ of lysis buffer (Tris Base $50 \mathrm{mM}$ at pH 7.2, $1 \mathrm{mM}$ EDTA, $100 \mathrm{mM}$ $\mathrm{NaCl}, 1 \mathrm{mM}$ PMSF, $1 \mathrm{mM}$ ortovanadate, $0.1 \%$ Triton $\mathrm{X}-100$ ) and centrifuged at $10,000 \mathrm{rpm}$ for $10 \mathrm{~min}$. The supernatant with cellular proteins were dissolved in SDS-PAGE solution [Tris $60 \mathrm{mM}$ to $\mathrm{pH} 6.5,10 \%(\mathrm{w} / \mathrm{v})$ glycerol, $5 \%(\mathrm{w} / \mathrm{v})$ $\beta$-mercaptoethanol, $20 \%$ (w/v) SDS, and $0.025 \%$ (w/v) bromophenol blue] and denatured by boiling $(5 \mathrm{~min})$ and the mixture (30 sec) was stirred. The total amount of protein in each lane was $30 \mu \mathrm{g}$ determined by the use of bicinchoninic acid method (Bio-Rad Laboratories, Hercules, CA, USA) and BSA as standard, plus protein standard markers (Bio-Rad Laboratories). After fractionation by SDS-PAGE gels $(7 \times 14 \mathrm{~cm})$, proteins were electro-transferred onto PVDF membrane (Amersham Biosciences, Buckinghamshire, UK) using a transfer apparatus (Bio-Rad Laboratories). The transferred membranes were blocked for $2 \mathrm{~h}$ in $10 \%$ defatted milk-TBS-0.1\% and then incubated for $2 \mathrm{~h}$ at room temperature with the corresponding primary antibody (1:200) Bcl-2 (C-2) sc-7382, Bax (N-20) sc-493, caspase-8 (8CSP03) sc-56070, NF-кB p52 (C-5) sc-7386 and $\beta$-actin (C4) sc-47778 followed by incubation with goat anti-mouse IgG-HRP sc-2302 or goat anti-rabbit IgG-HRP sc-2004 secondary antibody $(1: 5,000)$ in $5 \%$ milk dry defatted with TBS-0.1\%-Tween. All steps were performed at room temperature. The cell transfers were tested with mouse anti-actin antibody as control. Immunoreactive bands were displayed using the ECL ${ }^{\mathrm{TM}}$ detection method Western Blotting detection reagent (Amersham Biosciences, Dübendorf, Switzerland) and exposing the membrane to X-ray film. The experiments were performed three times.

RNA extraction and cDNA synthesis. Total RNA was isolated using TRIzol reagent (Invitrogen Corp., Carlsbad, CA, USA) according to the manufacturer's recommendations. Total RNA (2 $\mu \mathrm{g}$ measured by spectrophotometry to $260 \mathrm{~nm}$ wavelength) was reverse-transcribed to cDNA using High Capacity cDNA reverse transcription kit (Applied Biosystems, Carlsbad, CA, USA) and 10 units of RNase inhibitor (Applied Biosystems).

Differentialdisplay-reverse transcriptase-PCR (DD-RT-PCR). Two microliters $(\mu \mathrm{l})$ were used from cDNA obtained in $23 \mu \mathrm{l}$ containing PCR Nucleotide Mix (Promega, Madison, WI, USA) and $5 \mu \mathrm{M}$ of each primer for the target genes $\mathrm{Bax}, \mathrm{Bcl}-\mathrm{xL}$, caspase-8, caspase-9, NF- $\kappa B$ and $I \kappa B \alpha$. $\beta$-actin was used as reference gene. The reaction was performed in a Mastercycler personal (Eppendorf) with the following conditions: $94^{\circ} \mathrm{C}$ for $10 \mathrm{~min}$, followed by 25 cycles for melting temperature of each primer (Table I) for $30 \mathrm{sec}$, and $72^{\circ} \mathrm{C}$ for $30 \mathrm{sec}$, to finish $72^{\circ} \mathrm{C}$ for $5 \mathrm{~min}$ (Table II). The PCR products were run on a $2 \%(\mathrm{w} / \mathrm{v})$ agarose gel with ethidium bromide $(5 \mathrm{mg} / \mathrm{ml})$ and photographed and then analyzed.

DNA fragmentation. The cell lines were lysed with $500 \mu \mathrm{l}$ of lysis buffer (Tris- $\mathrm{HCl} 10 \mathrm{mM}$ at $\mathrm{pH} 8.0,10 \mathrm{mM}$ EDTA, $0.5 \%$ Triton X-100) for $30 \mathrm{~min}$ on ice, followed by $1 \mathrm{~h}$ at $37^{\circ} \mathrm{C}$ in $1 \mu \mathrm{l}$ of ribonuclease A (10 mg/ml) (Sigma-Aldrich) and $2 \mathrm{~h}$ at $60^{\circ} \mathrm{C}$ 
Table I. Primers of genes selected for differential display conventional PCR analysis.

\begin{tabular}{|c|c|c|}
\hline Gene name & Primer sequences ${ }^{\mathrm{a}}$ & Product length $(\mathrm{bp})^{\mathrm{b}}$ \\
\hline \multirow[t]{2}{*}{ Bax } & Forward: GCGAGTGTCTCAAGCGCATC & \\
\hline & Reverse: CCAGTTGAAGTTGCCGTCAGAA & 143 \\
\hline \multirow[t]{2}{*}{$B c l-x L$} & Forward: CTGAATCGGAGATGGAGACC & \\
\hline & Reverse: TGGGATGTCAGGTCACTGAA & 211 \\
\hline \multirow[t]{2}{*}{ Caspase-8 } & Forward: CATCCAGTCACTTTGCCAGA & \\
\hline & Reverse: GCATCTGTTTCCCCATGTTT & 128 \\
\hline \multirow[t]{2}{*}{ Caspase-9 } & Forward: CCAGAGATTGCGAAACCAGAGG & \\
\hline & Reverse: GAGCACCGACATCACCAAATCC & 88 \\
\hline \multirow[t]{2}{*}{$N F-\kappa B(\operatorname{Rel} A)$} & Forward: ATCTGCCGAGTGAACCGAAACT & \\
\hline & Reverse: CCAGCCTGGTCCCGTGAAA & 114 \\
\hline \multirow[t]{2}{*}{$I \kappa B \alpha$} & Forward: CTCCGAGACTTTCGAGGAAATAC & \\
\hline & Reverse: GCCATTGTAGTTGGTAGCCTTCA & 135 \\
\hline \multirow[t]{2}{*}{$\beta$-actin } & Forward: ACTACCTCATGAAGATCCTC & \\
\hline & Reverse: TAGAAGCATTTGCGGTGGACGATGG & 569 \\
\hline
\end{tabular}

Table II. Protocol for PCR analysis.

\begin{tabular}{lccc}
\hline Gene name & Cycles no. & PCR step & Temperature/time \\
\hline Bax & 25 & Annealing & $58^{\circ} \mathrm{C} / 30 \mathrm{sec}$ \\
Bcl- $x L$ & 25 & Annealing & $55^{\circ} \mathrm{C} / 30 \mathrm{sec}$ \\
Caspase- 8 & 25 & Annealing & $55^{\circ} \mathrm{C} / 30 \mathrm{sec}$ \\
Caspase-9 & 25 & Annealing & $58^{\circ} \mathrm{C} / 30 \mathrm{sec}$ \\
$N F-\kappa B$ & & & \\
(Rel A) & 25 & Annealing & $58^{\circ} \mathrm{C} / 30 \mathrm{sec}$ \\
I B $\alpha$ & 25 & Annealing & $55^{\circ} \mathrm{C} / 30 \mathrm{sec}$ \\
$\beta$-actin & 25 & Annealing & $58^{\circ} \mathrm{C} / 30 \mathrm{sec}$ \\
\hline
\end{tabular}

Every PCR initial cycle of $94^{\circ} \mathrm{C}$ for 10 min was necessary to activate Taq polymerase, $94^{\circ} \mathrm{C}$ for $30 \mathrm{sec}$ for a DNA denaturation, $72^{\circ} \mathrm{C}$ for $30 \mathrm{sec}$ for extension step and a final cycle of $72^{\circ} \mathrm{C}$ for 5 min was utilized to complete the amplification produced.

with $25 \mu \mathrm{l}$ of proteinase $\mathrm{K}(20 \mathrm{mg} / \mathrm{ml})$. Then, $500 \mu \mathrm{l}$ of basic phenol-chloroform (Winkler LTDA, Santiago, Chile) was added and centrifuged at $4^{\circ} \mathrm{C}(13,200 \mathrm{rpm}$ for $15 \mathrm{~min})$. The supernatant was recovered and added with isopropanol overnight at $-20^{\circ} \mathrm{C}$. It was centrifuged to $13,200 \mathrm{rpm}$ for $15 \mathrm{~min}$ at $4^{\circ} \mathrm{C}$ and the pellet was suspended in $30 \mu \mathrm{l}$ of molecular water. The product was run on a $1.5 \%$ (w/v) agarose gel with $5 \mathrm{mg} / \mathrm{ml}$ ethidium bromide and photographed.

Statistical analysis. The results were expressed as the average \pm standard error of the mean (SEM) and analyzed using one way ANOVA followed by Dunnet's test. The P-value $<0.05$ was considered significant. Inhibitor concentration at $50 \%\left(\mathrm{IC}_{50}\right)$ was calculated by a non-linear regression curve using GraphPad Prism 6.0 for Windows (GraphPad Software, Inc., San Diego, CA, USA).

\section{Results}

The MTT assay was used to determine the effect of noscapine on cell viability in vitro. Noscapine effectively had a dosedependent cytotoxic effect after 24 and $48 \mathrm{~h}$ in MCF-10F, MCF-7 and MDA-MB-231 cell lines (Fig. 1). Noscapine had an $\mathrm{IC}_{50}$ of 58,54 and $29 \mu \mathrm{M}$ for MCF-10F, MCF-7 and MDA-MB231 cell lines at $24 \mathrm{~h}$, respectively. The $\mathrm{IC}_{50}$ was of 53, 30 and $20 \mu \mathrm{M}$ for MCF-10F, MCF-7 and MDA-MB-231 cell lines at $48 \mathrm{~h}$, respectively. All the experiments were performed with their respective $\mathrm{IC}_{50}$ at $48 \mathrm{~h}$ for each cell line.

To determine whether apoptosis was the major mechanism of cell death induced by noscapine, internucleosomal DNA fragmentation was investigated in the three cell lines. Results showed that control cell lines did not present fragmentation. MCF-10F treated with noscapine did not show clearly ladder DNA fragmentation (Fig. 2A). However, results clearly showed that MCF-7, and MDA-MB-231 breast cancer cell lines (Fig. 2B and $\mathrm{C}$ ) treated with noscapine had ladder DNA fragmentation.

Results showed that noscapine significantly $(\mathrm{P}<0.001)$ increased Bax protein expression but there was no significance of Bcl-2 (Fig. 3A and B) in MCF-10F cell line when compared to their counterparts. Noscapine significantly $(\mathrm{P}<0.05)$ increased Bax protein expression and significantly $(\mathrm{P}<0.05)$ decreased of Bcl-2 in MCF-7 breast cancer cell line (Fig. 3C and $\mathrm{D})$. Noscapine also significantly $(\mathrm{P}<0.05)$ increased Bax protein expression and it significantly $(\mathrm{P}<0.001)$ decreased Bcl-2 protein expression in MDA-MB-231 breast cancer cell line (Fig. 3E and F) in comparison to their counterparts.

Fig. 4A shows Bax/Bcl-2 ratio evaluated from protein expression in MCF-10F cells treated with noscapine. The drug 

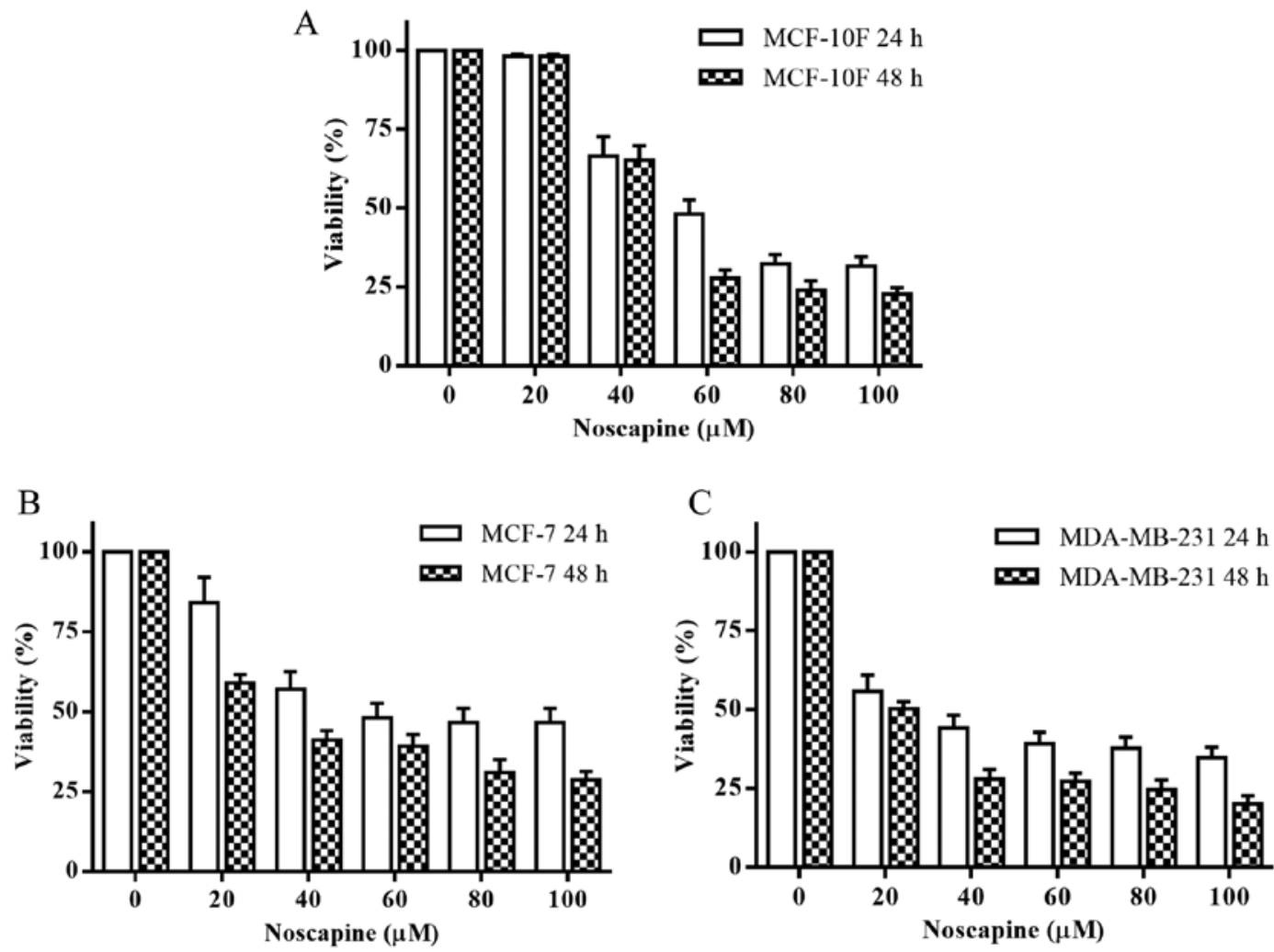

Figure 1. Cell viability effects of noscapine in cell lines. (A) MCF-10F, (B) MCF-7 and (C) MDA-MB-231 were exposed to different doses of noscapine $(0-100 \mu \mathrm{M})$ and incubated for 24 and $48 \mathrm{~h}$, then determined by using the MTT assay and an automated cell counter. Bars represent the mean \pm SEM of three independent experiments.
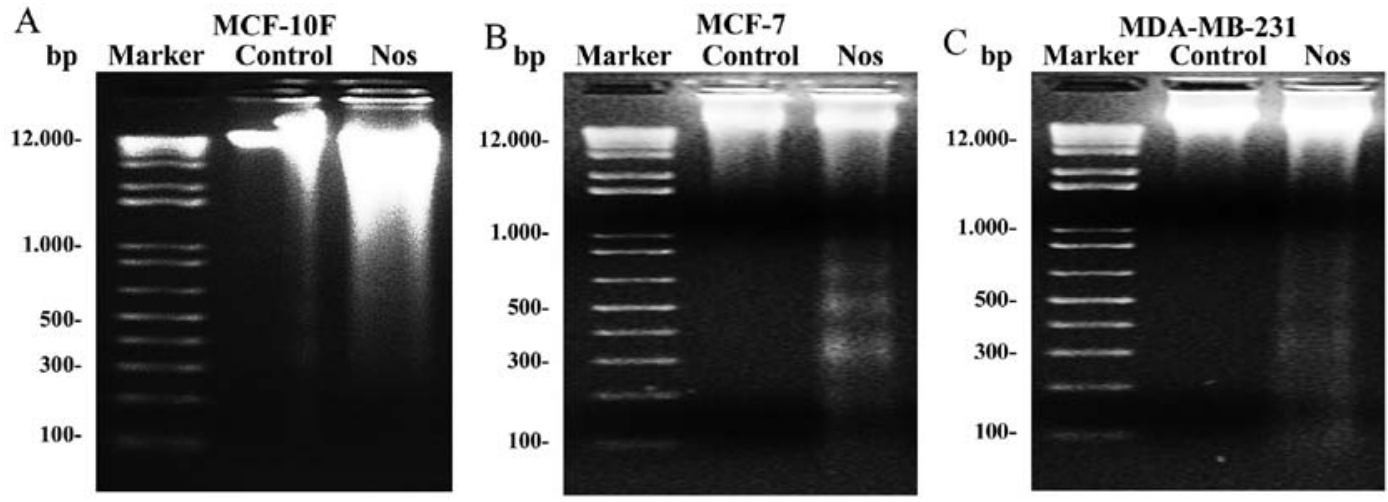

Figure 2. Internucleosomal DNA fragmentation in (A) MCF-10F, (B) MCF-7 and (C) MDA-MB-231 cell lines treated with noscapine (53, 30 and $20 \mu \mathrm{m}$, respectively) evaluated after $48 \mathrm{~h}$.

significantly $(\mathrm{P}<0.001)$ increased the ratio in this cell line from 0.03 to 0.70 of the proapoptotic protein Bax in relation to an antiapoptotic protein Bcl-2. The MCF-7 cell line treated with noscapine also significantly $(\mathrm{P}<0.001)$ increased the $\mathrm{Bax} / \mathrm{Bcl}-2$ ratio from 0.71 to 1.08 as seen in Fig. 4B. Results showed that noscapine significantly $(\mathrm{P}<0.001)$ increased $\mathrm{Bax} / \mathrm{Bcl}-2$ ratio from 0.99 to 3.64 in MDA-MB-231 cells (Fig. 4C).

Studies on gene expression showed that noscapine-treated MCF-10F cells significantly $(\mathrm{P}<0.05)$ increased Bax, caspase- 8 and $I \kappa B \alpha$ (Fig. 5). However, there was no change in $B c l-x L$, caspase -9 and $N F-\kappa B$ by the effect of this drug. Fig. 6 shows that noscapine significantly $(\mathrm{P}<0.05)$ increased Bax, caspase -9 and $I \kappa B \alpha$, gene expression while significantly $(\mathrm{P}<0.05)$ decreased the levels of $B c l-x L$ and $N F-\kappa B$ in MCF-7. Caspase-8 did not show any significance by the effect of noscapine. Furthermore, noscapine treated- MDA-MB-231 cells significantly $(\mathrm{P}<0.05)$ increased Bax, caspase-8, caspase-9 levels of gene expression, but $I \kappa B \alpha$ was not significantly different from its counterparts. Noscapine significantly $(\mathrm{P}<0.05)$ decreased $B c l-x L$ and $N F-\kappa B$ gene expression in MDA-MB-231 cells as observed in Fig. 7A and quantified in Fig. 7B. As shown in Fig. 8 noscapine-treated cell lines exhibited increased cleavage of caspase- 8 into cleaved caspase- 8 in MCF-7 and MDA-MB-231 compared to their respective controls. MCF-10F cell line did not show cleavage.

Fig. 9 shows NF-кB (p52) protein expression that significantly $(\mathrm{P}<0.05)$ increased in MCF-10F cells by noscapine and 
A

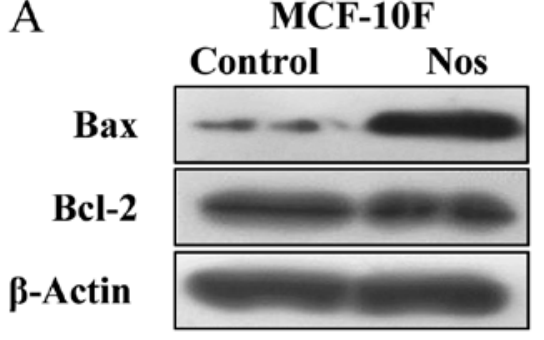

$\mathrm{C}$

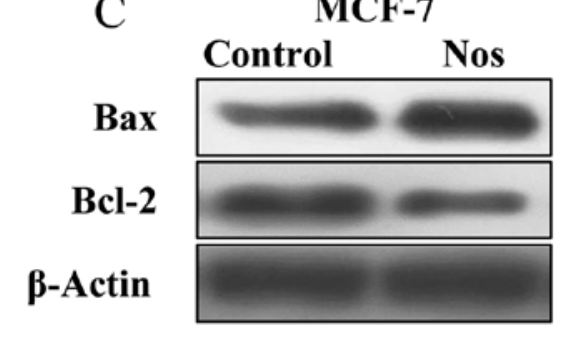

$\mathrm{E}$

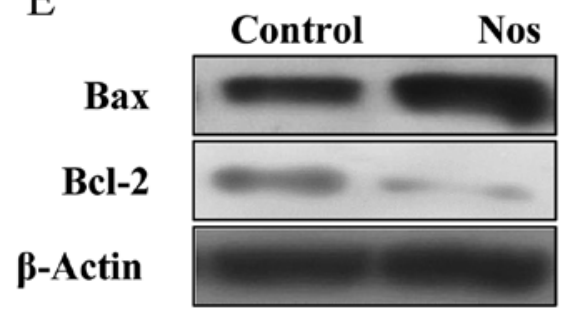

$23 \mathrm{kDa}$

$26 \mathrm{kDa}$

42 kDa

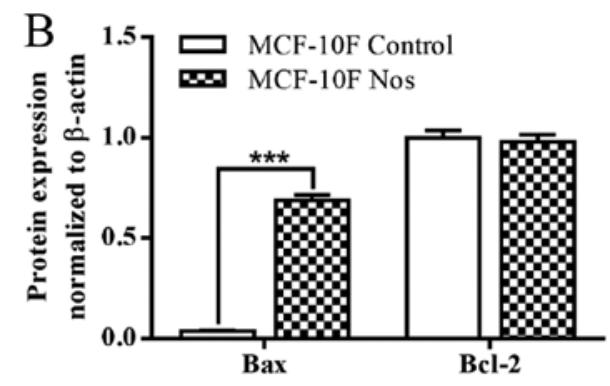

$23 \mathrm{kDa}$

26 kDa

$42 \mathrm{kDa}$

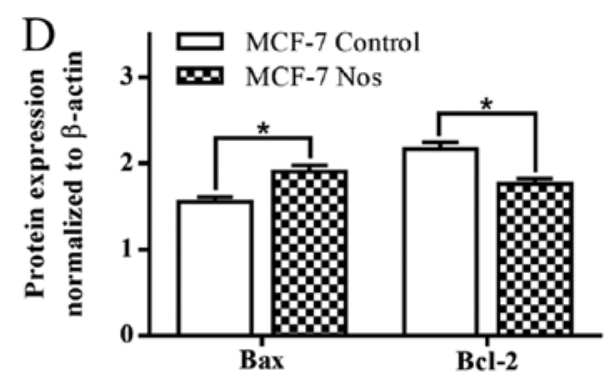

$23 \mathrm{kDa}$

$26 \mathrm{kDa}$

$42 \mathrm{kDa}$

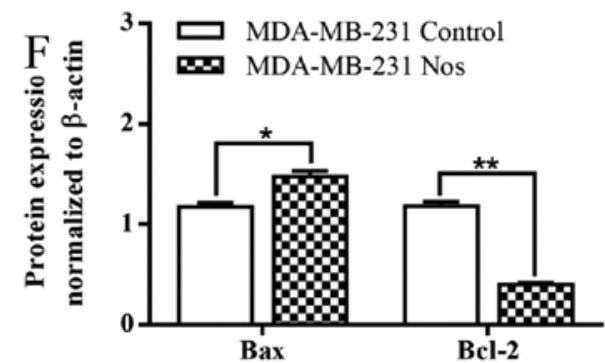

Figure 3. Western blot analysis performed to analyze the expression of Bax and Bcl-2 proteins in (A) MCF-10F, (C) MCF-7 and (E) MDA-MB-231 cell lines treated with noscapine evaluated at $48 \mathrm{~h}$. $\beta$-actin was used as control for loading. Western blot results of MCF-10F, MCF-7 and MDA-MB-231 (B, D and F, respectively) were quantified with Adobe Photoshop program and were expressed as average density to $\beta$-actin. Bars represent the mean \pm SEM of three independent experiments. $\left({ }^{*} \mathrm{P}<0.05,{ }^{* *} \mathrm{P}<0.01\right.$ and ${ }^{* * *} \mathrm{P}<0.001$ vs. control cells).
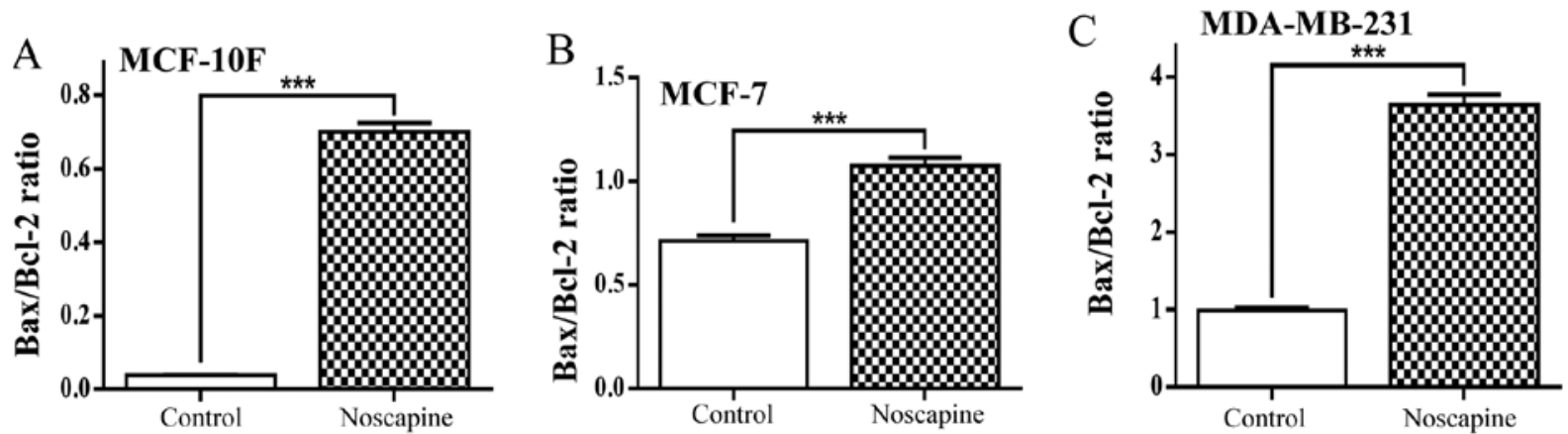

Figure 4. Ratio Bax/Bcl-2 from expression protein in (A) MCF-10F, (B) MCF-7 and (C) MDA-MB-231 cell lines. Bars represent the mean \pm SEM of three independent experiments $\left({ }^{*} \mathrm{P}<0.05,{ }^{* *} \mathrm{P}<0.01\right.$ and ${ }^{* * * *} \mathrm{P}<0.001$ vs. control cells).

decreased NF- $\kappa \mathrm{B}$ (p100) protein expression when compared to its counterparts. After treatment with noscapine, MCF-7 and MDA-MB-231 cell lines significantly $(\mathrm{P}<0.05$ and $\mathrm{P}<0.001$, respectively) decreased the levels of both p100 and p52 (Fig. 9C-F).

\section{Discussion}

Our results showed that noscapine had a dose-dependent cytotoxic effect after 24 and $48 \mathrm{~h}$ in the three cell lines.
The $\mathrm{IC}_{50}$ demonstrated that noscapine had specific cytotoxic effect in MCF-7 and MDA-MB-231 breast cancer cell lines requiring higher doses in $\mathrm{MCF}-10 \mathrm{~F}$ normal cell line. It was also demonstrated that triple-negative cells MDA-MB-231 was more sensitive than triple-positive MCF-7 cells in treatment with noscapine which agrees with the results of other studies $(21,22)$. Noscapine provides promise as an effective anticancer agent with lower toxicity on normal cells.

Internucleosomal DNA fragmentation was investigated in the three cell lines to determine whether apoptosis was 

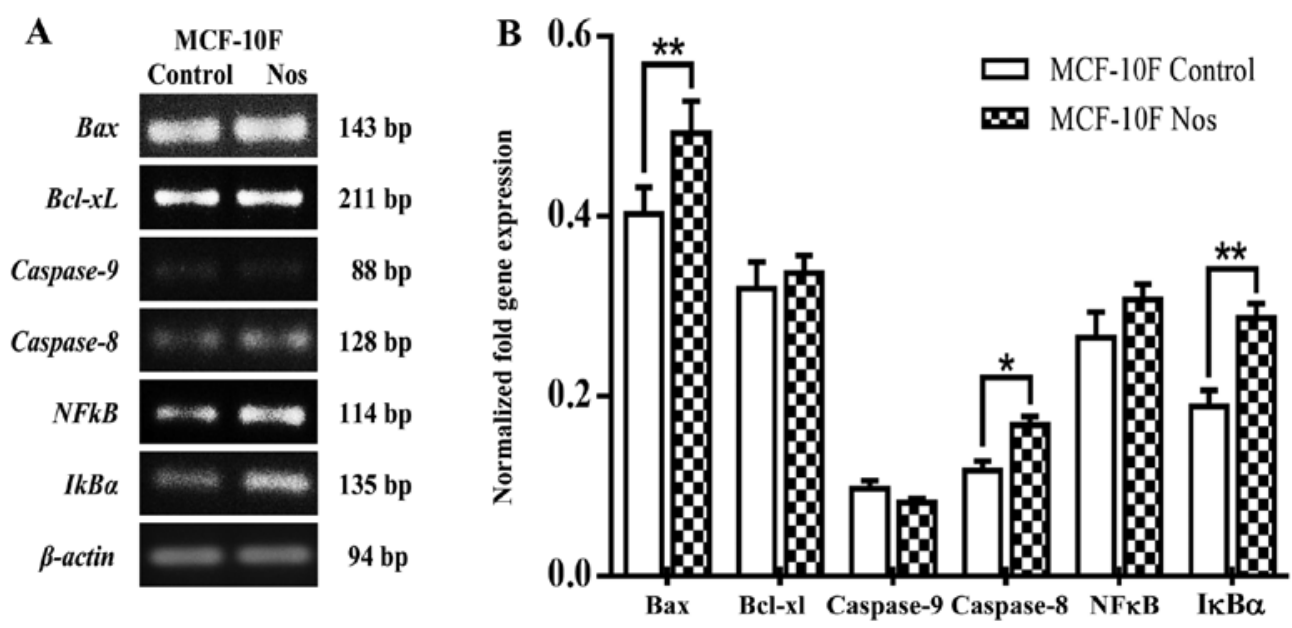

Figure 5. (A) Effect of noscapine on Bax, Bcl-xL, caspase-8, caspase-9, NF- $\mathrm{B}$ and I $\mathrm{kB} \alpha$ gene expression by conventional PCR in MCF-10F cell line treated with noscapine (53, 30 and $20 \mu \mathrm{m}$, respectively) evaluated after $48 \mathrm{~h}$. (B) The conventional PCR results was quantified with Adobe Photoshop program and were expressed as average density to $\beta$-actin. Bars represent the mean \pm SEM of three independent experiments. $\left({ }^{*} \mathrm{P}<0.05,{ }^{* *} \mathrm{P}<0.01\right.$ and ${ }^{* * *} \mathrm{P}<0.001$ vs. control cells).
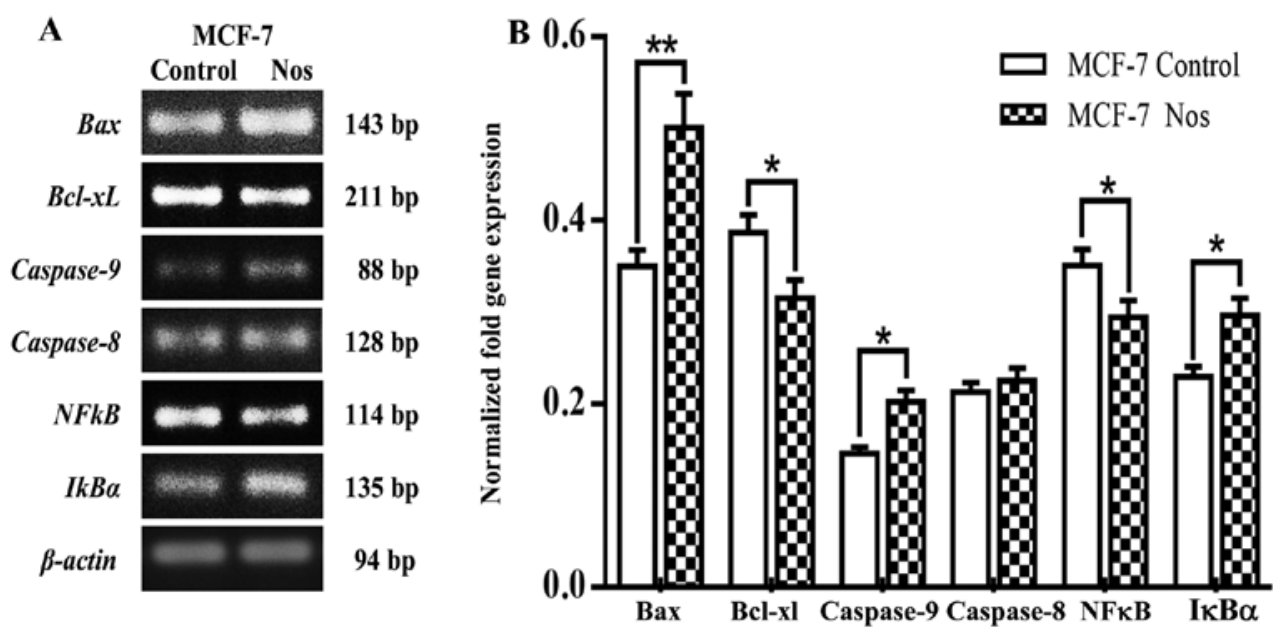

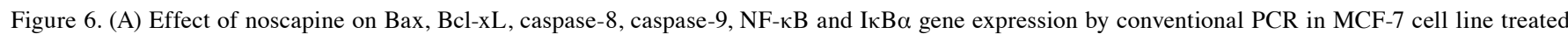
with noscapine (53,30 and $20 \mu \mathrm{m}$, respectively) evaluated at $48 \mathrm{~h}$. (B) The conventional PCR results was quantified with Adobe Photoshop program and were expressed as average density to $\beta$-actin. Bars represent the mean \pm SEM of three independent experiments. $\left({ }^{*} \mathrm{P}<0.05,{ }^{* *} \mathrm{P}<0.01\right.$ and ${ }^{* * * *} \mathrm{P}<0.001$ vs. control cells).
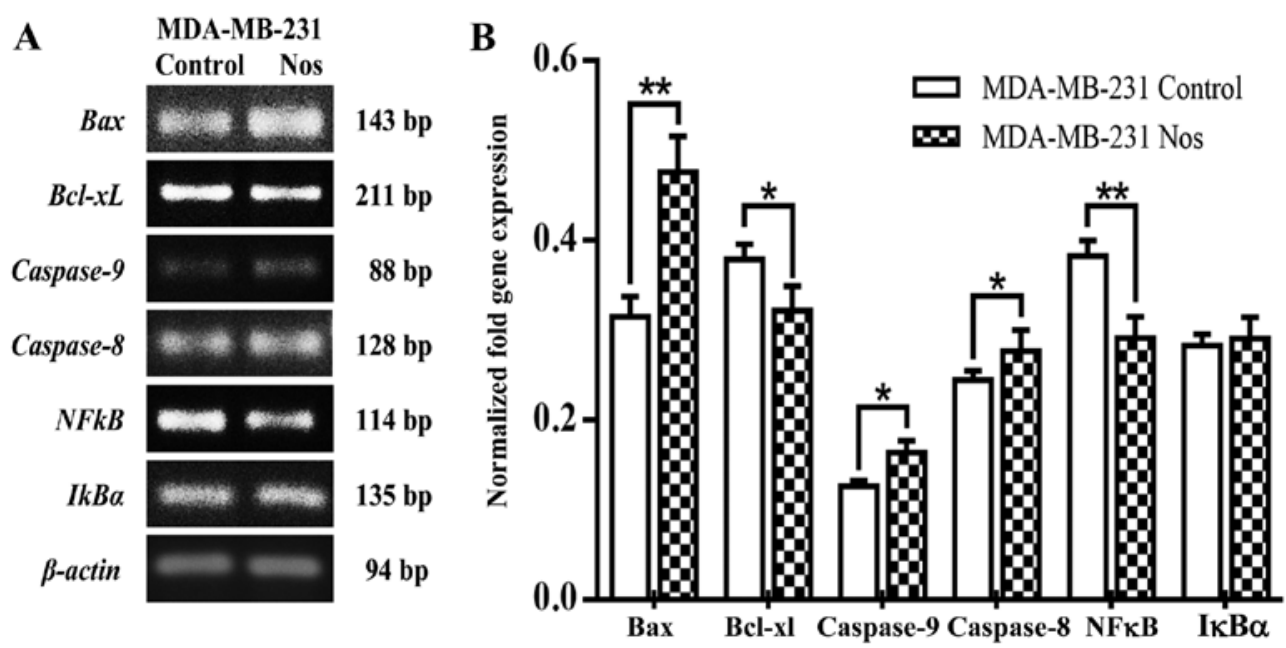

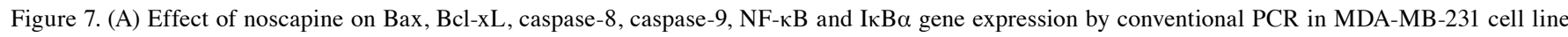
treated with noscapine (53,30 and $20 \mu \mathrm{m}$, respectively) evaluated at $48 \mathrm{~h}$. (B) The conventional PCR results were quantified with Adobe Photoshop program and were expressed as average density to $\beta$-actin. Bars represent the mean \pm SEM of three independent experiments. $\left({ }^{*} \mathrm{P}<0.05,{ }^{* * *} \mathrm{P}<0.01\right.$ and ${ }^{* * * *} \mathrm{P}<0.001$ vs. control cells). 


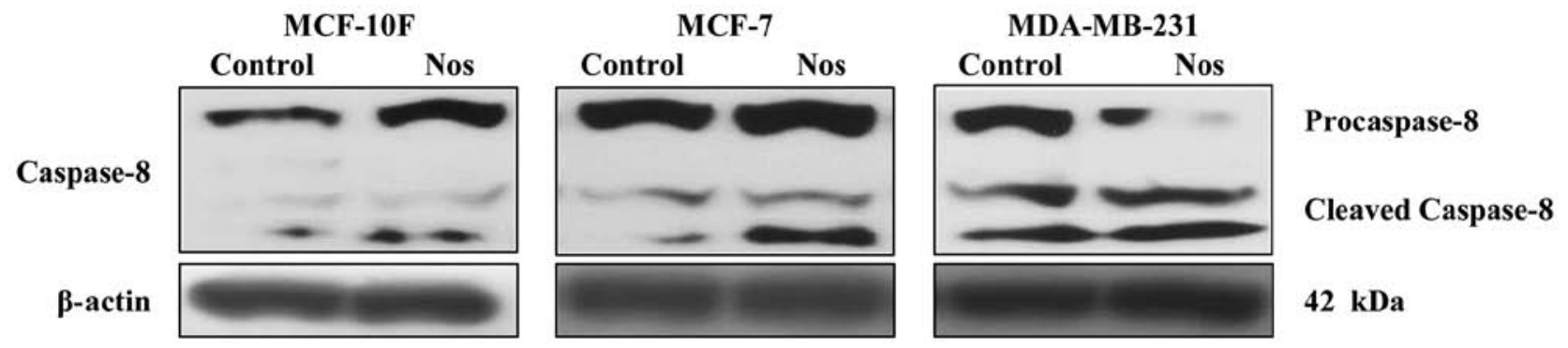

Figure 8. Effect of noscapine on cleavage of caspase-8 in MCF-10F, MCF-7 and MDA-MB-231 cell lines treated with noscapine (53, 30 and $20 \mu \mathrm{m}$, respectively) evaluated by western blot analysis at $48 \mathrm{~h}$. $\beta$-actin was used as control for loading.
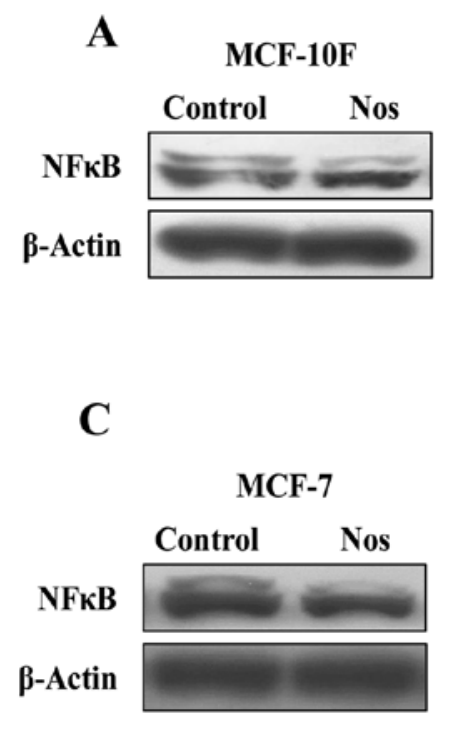

$100 \mathrm{kDa}$
$52 \mathrm{kDa}$
$42 \mathrm{kDa}$

$\mathbf{E}$

MDA-MB-231

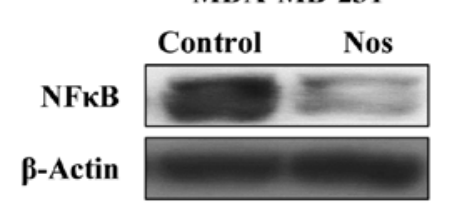

$52 \mathrm{kDa}$

$42 \mathrm{kDa}$
$100 \mathrm{kDa}$
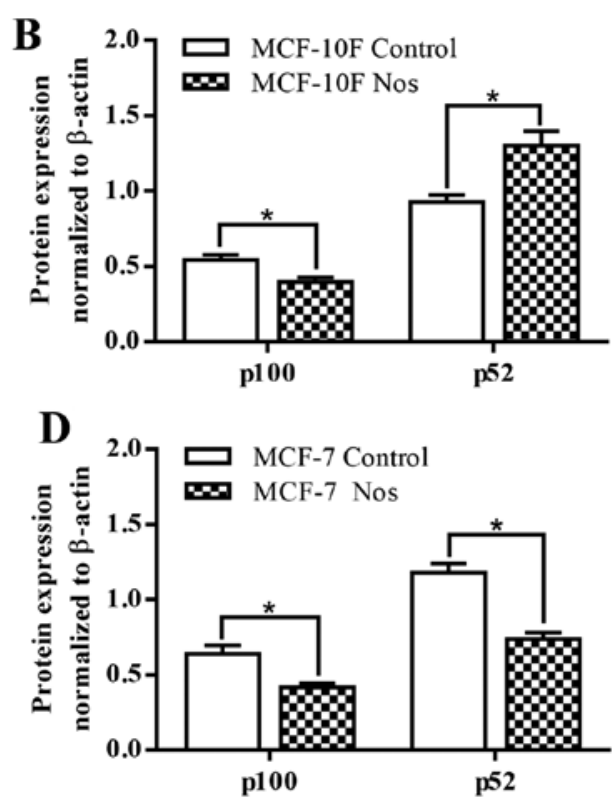

F

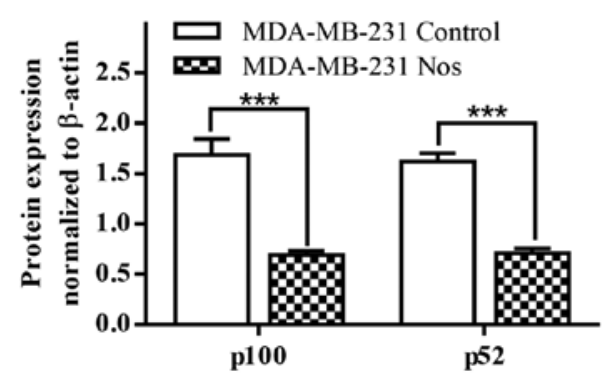

Figure 9. Western blot analysis was performed to analyze the expression of NF-kB (p100/p52) in (A) MCF-10F, (C) MCF-7 and (E) MDA-MB-231 cell lines treated with noscapine (53,30 and $20 \mu \mathrm{m}$, respectively) evaluated at $48 \mathrm{~h}$. $\beta$-actin was used as control for loading. Western blot results of MCF-10F, MCF-7 and MDA-MB-231 (B, D and F, respectively) were quantified with Adobe Photoshop program and were expressed as average density to $\beta$-actin. Bars represent the mean \pm SEM of three independent experiments. $\left({ }^{*} \mathrm{P}<0.05,{ }^{* *} \mathrm{P}<0.01\right.$ and ${ }^{* * * *} \mathrm{P}<0.001$ vs. control cells).

the major mechanism of cell death induced by noscapine. Internucleosomal DNA fragmentation was observed in the three cell lines studied. These results showed that cytotoxic effect of noscapine was mediated by apoptosis, being clearly observed on breast cancer cells. Previous research have shown that noscapine induced apoptosis in vitro in various types of cancer such as ovarian, neuroblastoma, colon, prostate and breast cancer among others $(18,20,23,24)$.

Noscapine increased Bax protein expression and there was no significance of $\mathrm{Bcl}-2$ in MCF-10F cell line when compared to their counterparts. This drug increased Bax protein expression and decreased Bcl-2 in MCF-7 and MDA-MB-231 breast cancer cell lines in comparison to their counterparts. Similar results were observed by other researchers and were related with $\mathrm{Bax} / \mathrm{Bcl}-2$ ratio $(23,25)$. Bax/Bcl-2 ratio was evaluated from protein expression in $\mathrm{MCF}-10 \mathrm{~F}$ cells treated with noscapine and increased ratio from 0.03 to 0.70 of Bax was found in relation to Bcl-2. The MCF-7 and MDA-MB-231 cells increased the ratio from 0.71 to 1.08 and from 0.99 to 3.64 , respectively. The decrease in ratio $\mathrm{Bax} / \mathrm{Bcl}-2$ is characteristic of cancer 
cells where proapoptotic proteins are diminished compared to antiapoptotic proteins suggesting that mitochondrial apoptosis pathway is suppressed as indicated in other studies in different types of cancer cells by several authors $(20,23,25)$. Noscapinetreated cells increased the expression of pro-apoptotic genes and decreased anti-apoptotic gene expression. This finding was consistent with the expression of proteins, suggesting that apoptosis induced by noscapine was due to the increase of gene expression of Bax and the decrease of $B c l-x L$ gene expression.

Caspase-9 gene expression increased in $\mathrm{MCF}-7$ and MDA-MB-231 cancer cell lines after treatment with noscapine when compared to its counterpart. Caspase- 8 increased gene expression in MCF-10F and MDA-MB-231 but not in MCF-7. Based on these data, it can be assumed that noscapine-induced apoptosis is probably due to the involvement of caspase- 8 and caspase-9, activating the extrinsic and intrinsic apoptosis pathways as reported previously (26-28). Noscapine exhibited an increased cleavage of caspase- 8 into cleaved caspase- 8 in MCF-7 and MDA-MB-231 compared to their respective controls. MCF-10F cells did not show any cleavage. Studies have shown that NF- $\kappa$ B plays an important role on gene expression that regulates cell death, leading to the upregulation of antiapoptotic and pro-survival genes, such as members of the Bcl-2 family and inhibitor apoptosis proteins. Anti-apoptotic genes and proteins increased in breast cancer cell lines mediated by $\mathrm{NF}-\kappa \mathrm{B}$ as well as decreased proapoptotic gene and protein expression (29-31).

Our results showed that antiapoptotic gene and protein expression diminished by the effect of noscapine, and proapoptotic gene and protein expression increased. Both effects probably are due not only to decreased NF- $\kappa \mathrm{B}$ gene and protein expression, but also to increase of $\mathrm{I} \kappa \mathrm{B} \alpha$ induced by noscapine, which suppresses activation of NF- $\kappa$ B. Thus, our results showed that $N F-\kappa B$ gene and protein expression increased in MCF-7 and MDA-MB-231 compared to $\mathrm{MCF}-10 \mathrm{~F}$ cell line, but noscapine treatment induced a decrease in MCF-7 and MDA-MB-231 breast cancer cell lines compared to its counterparts. The translocation of NF- $\kappa \mathrm{B}$ to the nucleus is preceded by degradation of $I \kappa B \alpha$ which is an inhibitor of NF- $\kappa \mathrm{B}(15,16,29,32)$. The present results showed that noscapine increased $I \kappa B \alpha$ gene expression in MCF-10F and MCF-7 in comparison to its counterparts. Furthermore, previous studies have shown high levels of NF- $\kappa$ B polypeptides (both p100 and p52) in mammary carcinoma cell lines and primary tumors compared to normal breast cells $(17,33,34)$. These results with noscapine in breast cancer cell lines are the first to be published; however, studies have been reported in other cancers $(22,32)$.

We conclude that noscapine selectively induced apoptosis in breast cancer cell lines, with little effect in normal breast cell line and with stronger effect on triple negative breast cancer cell line, possible through $\mathrm{I} \kappa \mathrm{B} \alpha$ which inactivates $\mathrm{NF}-\kappa \mathrm{B}$, triggering the expression of genes and proteins and favoring intrinsic and extrinsic apoptosis pathways.

\section{Acknowledgements}

The technical support of Guiliana Rojas, Georgina Vargas Marchant and Leodán A. Crispin and helpful suggestions given by Richard Ponce-Cusi are greatly appreciated. The present study was supported by the Grant support FONDECYT \#1120006 (G.M.C) and MINEDUC-UTA (G.M.C).

\section{References}

1. Siegel RL, Miller KD and Jemal A: Cancer statistics, 2015. CA Cancer J Clin 65: 5-29, 2015.

2. Torre LA, Bray F, Siegel RL, Ferlay J,Lortet-Tieulent J and Jemal A: Global cancer statistics, 2012. CA Cancer J Clin 65: 87-108, 2015.

3. Tao Z, Shi A, Lu C, Song T, Zhang Z and Zhao J: Breast cancer: Epidemiology and etiology. Cell Biochem Biophys 72: 333-338, 2015.

4. Cadoo KA, Fornier MN and Morris PG: Biological subtypes of breast cancer: Current concepts and implications for recurrence patterns. Q J Nucl Med Mol Imaging 57: 312-321, 2013.

5. Wong RS: Apoptosis in cancer: From pathogenesis to treatment. J Exp Clin Cancer Res 30: 87, 2011.

6. Sharifi S, Barar J, Hejazi MS and Samadi N: Doxorubicin changes $\mathrm{Bax} / \mathrm{Bcl}-\mathrm{xL}$ ratio, caspase- 8 and 9 in breast cancer cells. Adv Pharm Bull 5: 351-359, 2015.

7. Ravi M, Tentu S, Baskar G, Rohan Prasad S, Raghavan S, Jayaprakash P, Jeyakanthan J, Rayala SK and Venkatraman G: Molecular mechanism of anti-cancer activity of phycocyanin in triple-negative breast cancer cells. BMC Cancer 15: 768, 2015.

8. Li MX and Dewson G: Mitochondria and apoptosis: Emerging concepts. F1000Prime Rep 7: 42, 2015.

9. Bargou RC, Daniel PT, Mapara MY, Bommert K, Wagener C, Kallinich B, Royer HD and Dörken B: Expression of the bcl-2 gene family in normal and malignant breast tissue: Low bax-alpha expression in tumor cells correlates with resistance towards apoptosis. Int J Cancer 60: 854-859, 1995.

10. Vela L and Marzo I: Bcl-2 family of proteins as drug targets for cancer chemotherapy: The long way of $\mathrm{BH} 3$ mimetics from bench to bedside. Curr Opin Pharmacol 23: 74-81, 2015.

11. Besbes S, Mirshahi M, Pocard M and Billard C: New dimension in therapeutic targeting of BCL-2 family proteins. Oncotarget 6 : 12862-12871, 2015.

12. Bai L and Wang S: Targeting apoptosis pathways for new cancer therapeutics. Annu Rev Med 65: 139-155, 2014.

13. Hata AN, Engelman JA and Faber AC: The BCL2 family: Key mediators of the apoptotic response to targeted anticancer therapeutics. Cancer Discov 5: 475-487, 2015.

14. Hassan M, Watari H, AbuAlmaaty A, Ohba Y and Sakuragi N: Apoptosis and molecular targeting therapy in cancer. Biomed Res Int 2014: 150845, 2014

15. Cao Y and Karin M: NF-kappaB in mammary gland development and breast cancer. J Mammary Gland Biol Neoplasia 8: 215-223, 2003.

16. Khan S, Lopez-Dee Z, Kumar R and Ling J: Activation of NF- $\mathrm{KB}$ is a novel mechanism of pro-survival activity of glucocorticoids in breast cancer cells. Cancer Lett 337: 90-95, 2013.

17. Wang W, Nag SA and Zhang R: Targeting the NF- $\mathrm{B}$ B signaling pathways for breast cancer prevention and therapy. Curr Med Chem 22: 264-289, 2015.

18. Ye K, Ke Y, Keshava N, Shanks J, Kapp JA, Tekmal RR, Petros J and Joshi HC: Opium alkaloid noscapine is an antitumor agent that arrests metaphase and induces apoptosis in dividing cells. Proc Natl Acad Sci USA 95: 1601-1606, 1998.

19. Mahmoudian M and Rahimi-Moghaddam P: The anti-cancer activity of noscapine: A review. Recent Patents Anticancer Drug Discov 4: 92-97, 2009.

20. Li S, He J, Li S, Cao G, Tang S, Tong Q and Joshi HC: Noscapine induced apoptosis via downregulation of survivin in human neuroblastoma cells having wild type or null p53. PLoS One 7: e40076, 2012.

21. Aneja R, Vangapandu SN, Lopus M, Viswesarappa VG, Dhiman N, Verma A, Chandra R, Panda D and Joshi HC: Synthesis of microtubule-interfering halogenated noscapine analogs that perturb mitosis in cancer cells followed by cell death. Biochem Pharmacol 72: 415-426, 2006.

22. Chougule MB, Patel AR, Jackson T and Singh M: Antitumor activity of Noscapine in combination with Doxorubicin in triple negative breast cancer. PLoS One 6: e17733, 2011.

23. Yang ZR, Liu M, Peng XL, Lei XF, Zhang JX and Dong WG: Noscapine induces mitochondria-mediated apoptosis in human colon cancer cells in vivo and in vitro. Biochem Biophys Res Commun 421: 627-633, 2012. 
24. Afzali M, Ghaeli P,Khanavi M,Parsa M,Montazeri H, Ghahremani MH and Ostad SN: Non-addictive opium alkaloids selectively induce apoptosis in cancer cells compared to normal cells. Daru 23: $16,2015$.

25. Liu M, Luo XJ, Liao F, Lei XF and Dong WG: Noscapine induces mitochondria-mediated apoptosis in gastric cancer cells in vitro and in vivo. Cancer Chemother Pharmacol 67: 605-612, 2011.

26. Chougule M, Patel AR, Sachdeva P, Jackson T and Singh M: Anticancer activity of Noscapine, an opioid alkaloid in combination with cisplatin in human non-small cell lung cancer. Lung Cancer 71: 271-282, 2011.

27. Heidari N, Goliaei B, Moghaddam PR, Rahbar-Roshandel N and Mahmoudian M: Apoptotic pathway induced by noscapine in human myelogenous leukemic cells. Anticancer Drugs 18: $1139-1147,2007$

28. Gonçalves A, Braguer D, Carles G, André N, Prevôt C and Briand C: Caspase-8 activation independent of CD95/CD95-L interaction during paclitaxel-induced apoptosis in human colon cancer cells (HT29-D4). Biochem Pharmacol 60: 1579-1584, 2000.

29. Barham W, Chen L, Tikhomirov O, Onishko H, Gleaves L, Stricker TP, Blackwell TS and Yull FE: Aberrant activation of $\mathrm{NF}-\kappa \mathrm{B}$ signaling in mammary epithelium leads to abnormal growth and ductal carcinoma in situ. BMC Cancer 15: 647, 2015.
30. Li F, Zhang J, Arfuso F, Chinnathambi A, Zayed ME, Alharbi SA Kumar AP, Ahn KS and Sethi G: NF-kB in cancer therapy. Arch Toxicol 89: 711-731, 2015

31. Sethi G, Ahn KS and Aggarwal BB: Targeting nuclear factor-kappa B activation pathway by thymoquinone: Role in suppression of antiapoptotic gene products and enhancement of apoptosis. Mol Cancer Res 6: 1059-1070, 2008.

32. Sung B, Ahn KS and Aggarwal BB: Noscapine, a benzylisoquinoline alkaloid, sensitizes leukemic cells to chemotherapeutic agents and cytokines by modulating the NF-kappaB signaling pathway. Cancer Res 70: 3259-3268, 2010.

33. Cogswell PC, Guttridge DC, Funkhouser WK and Baldwin AS Jr: Selective activation of NF-kappa B subunits in human breast cancer: Potential roles for NF-kappa B2/p52 and for Bcl-3. Oncogene 19: 1123-1131, 2000.

34. Wertz IE: TNFR1-activated NF- $\mathrm{BB}$ signal transduction: Regulation by the ubiquitin/proteasome system. Curr Opin Chem Biol 23: 71-77, 2014. 